Ret hi nki ng Ai nu Heri tage: A case Study of an Ai nu Set tl ement in Hokkai do, Japan

\begin{tabular}{|c|c|}
\hline 著者 & Si dney Cheung \\
\hline $\begin{array}{l}\text { jour nal or } \\
\text { publ i cat i on titl e }\end{array}$ & $\begin{array}{l}\text { 金沢大学日中無形文化遺産プロジェクト報告書= } \\
\text { Report of the I nt er nat i onal Wbr kshop }\end{array}$ \\
\hline vol une & 13 \\
\hline page $r$ ange & $37-45$ \\
\hline year & $2011-02-20$ \\
\hline URL & ht t p: //hdl . handl e. net /2297/28217 \\
\hline
\end{tabular}




\section{Rethinking Ainu Heritage: A Case Study of an Ainu Settlement in Hokkaido, Japan}

\section{SidNey CHeUnG}

With the colonization of Hokkaido since the Meiji era, Western technologies were introduced to Japan on one hand, while on the other hand the indigenous inhabitants-Ainu people's lifeways were negatively affected because of the assimilation policy. Since the late 1950s, ethnic tourism in Ainu settlements began to grow and Ainu hosts in traditional costumes were often seen in various tourist destinations in Hokkaido, Lake Akan was not exceptional. In this chapter, I will introduce the historic development of an Ainu settlement, explain the contested meanings of Ainu traditions, and furthermore investigate the social construction of Ainu culture in the postwar Japanese society from the culturalpolitical perspectives. With the focus on the Ainu settlement in Lake Akan, I aim to look closely into the changing indigenous living environments and relevant activities held during the last several decades in order to discern how Ainu heritage has been preserved and promoted as well as the social transformation Ainu people have undergone in the face of the globalizing Japanese society.

\section{Introduction}

Ainu, which originally means "human" in their language, is also the word currently used by Japanese to signify the indigenous people who settled in the land from northern Honshu to southern Kamchatka, including the southern Sakhalin Island, Kurile Islands and the lower reaches of the Amur River. The definition of Ainu has always been contested and even the number of Ainu people in existence had been a mystery until only recently. According to a population survey done by the Hokkaido local government in 1999 a total of 23,767 Ainu people (defined only as those who consider themselves Ainu) lived in Hokkaido prefecture. As mentioned by many Ainu people, however, the number of Ainu is probably larger than the one shown in the Hokkaido survey since there are many Ainu who hide their identity, reflecting the fact that many Ainu descendants are still trying to conceal their ethnic backgrounds and escape discrimination and social stigma.

During the Tokugawa period (1603-1868), there were approximately 20,000 to 30,000 Ainu inhabitants under the suzerainty of the Matsumae autonomous domain, located in the southern part of present-day Hokkaido. With the formation of the Japanese state under the Tokugawa shogunate, the Ainu identity, as distinguished from Japanese, was manipulated to enhance the prestige of those rulers of the Matsumae domain through their control over the "primitive" Ainu people. After the Meiji Restoration in 1868, the northern island Ezo-chi was renamed Hokkaido, and became the largest piece of land used by the modern Meiji nation-state for experimentation with imported Western technologies. At that time, Western technologies included the production of dairy products, salmon aquaculture, and canned product processing. These imported modern technologies enabled the supply of food to mainland Japan, justifying the idea of colonizing Hokkaido during the early Meiji period (1868-1912). With the 1899 Law for the Protection of
Native Hokkaido Aborigines, a policy of assimilation was forced upon the Ainu, and their social structure and living environment consequently went through a number of drastic changes as restrictions were put on their customs, language, and means of livelihood.' This law contained measures relating to land tenure and legal land expropriation which violated the Ainu people's territorial integrity as well as banning traditional subsistence strategies such as deer hunting and salmon fishing, and also forced the Ainu to cultivate rice for the Japanese mainland. In the last century, Ainu traditional lifestyles have disappeared, and their rights have been overlooked within Japanese society. Nowadays, the traditional Ainu settlement can no longer be seen, and the traditional grass-thatch Ainu huts are almost nonexistent, except for tourist areas where music and dancing performances and handicraft souvenirs are available.

In Japanese academia, Ainu studies was quite popular before 1970s. Apart from the economic growth that made overseas research easier, I speculate that the change could be the commodification of Ainu culture, impacted by the tourism industry, in which the "pure" Ainu cultural traditions could no longer be found. Even though it would be important to understand the underlying conflict between Ainu and Japanese within such a tourist arena, relevant ethnological and anthropological researches looking into the social and political aspects of Ainu-Japanese relations have been weakly developed. In particular, regarding the concerns of Ainu research among Japanese scholars, we realize that special attention was paid to the ethnic issue because of hostile relations between the Ainu and the Japanese in the past and "studying Ainu" turned out to be an area which Japanese researchers consider "sensitive" and difficult to be objective. ${ }^{2}$ Only until recently, Japanese researchers are interested in the meanings and significance of Ainu delegation in several world class events at the turn of the twentieth-century, including Saint Louis Olympic Games in 1904, Louisiana 
Purchase Exposition in 1904, Japan-British Exhibition of 1910 etc., especially how and why Ainu people were chosen to represent the modernized Japan at that time, which might consider a breakthrough. ${ }^{3}$ As for non-Japanese scholars, Ainu studies were silent for a long time after Romyn Hitchcock (1851-1923), Neil Gordon Munro (1863-1942), John Batchelor (1854-1944) etc., who did extensive studies in the early twentieth-century. Until the late 1960s, an article published in National Geographic broke the silence and renewed world interest in the "Sky People." "Since then, only a few books reported on the Ainu people and the most comprehensive English volume was probably an edited volume published after the exhibition of Ainu culture organized by Smithsonian Institution in 1999. ${ }^{5}$ Considering there is a lack of ethnographic study of Ainu people settled in Lake Akan and relevant heritage preservation in the past several decades, in this article, I aim to discuss the historical development of Lake Akan as an Ainu settlement and explain the contested meanings of Ainu traditions in the postwar Japan from the cultural-political perspectives. With the focus on the emergence of Ainu settlement in Lake Akan (Figure 5.1), I will look closely into the changing indigenous living environments and various cultural activities held during the last several decades in order to discern how Ainu heritage has been preserved and promoted as well as the social transformation Ainu people have undergone in the face of the globalizing Japanese society.

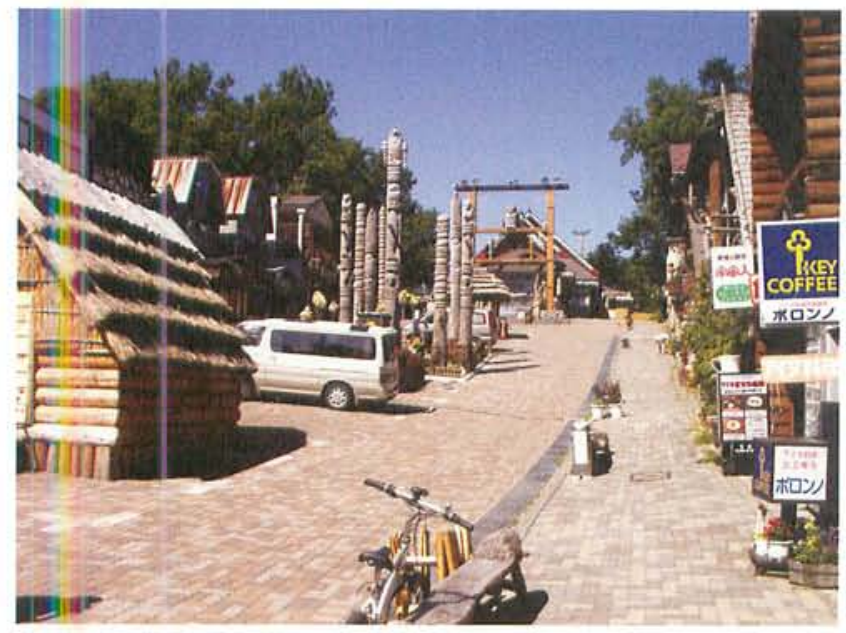

Figure 5.1: The overview of Ainu Kotan in Lake Akan.

\section{Meanings of Ainu Heritage in Japanese Society}

To better understand the meanings of Ainu heritage within the socio-political changes that have taken place in Japan, it is important to look into the changing meanings of Japanese culture since the postwar era. Japan's defeat in the Second World War brought about dramatic changes to Japanese nation, and the search for Japanese self-identity was seen as necessary for rebuilding the society. The importation of Western knowledge and technologies brought in enormous influences, as reflected in Japan's economic, political and military reconstruction; at the same time, the Emperor, as Japan's spiritual leader, went through a demotion from deity to human being, reflecting a new weakness in Japanese people's general sense of self-identification. American popular culture, commercialization, and urbanization were invading postwar Japanese society and were challenging the so-called Japanese cultural tradition. These factors brought the Japanese a subtle change in social values and initiated a quest for identity especially during the era of development into an economic power in the 1960s. In particular, the crisis of identity could be seen in numerous discussions of Japaneseness (Nihonjinron) by Japanese scholars as well as popular writers. In fact, the debate on Japaneseness reflects a crisis of identity, which in turn represents the change of attitudes of Japanese society towards the non-Japanese "others" including indigenous inhabitants, foreign migrants, foreigners etc. Therefore, the emergence of the discussions of Japaneseness in the postwar period indicates a change of Japanese society that can provide an understanding of the processes and dynamics of constructing both national and cultural identities in Japan.

Regarding the emphasis upon Japanese cultural uniqueness as a discourse in the last several decades, Aoki (1990) has suggested that the transformation of Japanese culture studies as well as the ideas of Japaneseness should be divided into the following periods for a better understanding. ${ }^{6}$ First of all, according to Aoki (1990), the immediate postwar period from 1945 to 1954 is the era in which Japanese culture was understood as its negative uniqueness signifying the images of imperialism and nationalism brought out during the Second World War. This was followed by rapid economic growth from 1955 to 1963, when Japanese culture was considered with emphasis upon historic relativity compared to the Western developing countries. From 1964 to 1976 , Aoki suggested that Japanese culture carried a positive uniqueness compared to the previous period. Starting with the Tokyo Olympic Games held in 1964, Japan not only demonstrated its continuing rapid economic growth but also, in the post-Olympics era, attracted overseas tourists to visit the country and general international attention to their culture. From 1977 to 1983 , Aoki suggested that, as the second part of positive period, Japanese culture became even more widely accepted at the international level. In particular, under the atmosphere of searching for a Japanese success model in a worldwide context, concepts such as Z-theory; M-form society; No. 1 country; Japanese management, etc., were popular and challenging concepts compared to the Western theories of modernization and economic achievement.

Simply speaking, after Japan had experienced recovery from the postwar poverty and political inferiority, it underwent a search for national identity and Japaneseness because of the economic success and self-recognition on the international stage. Then, we might want to ask about the situations of Ainu people in such a rapid social transformation. In fact, Ainu people have been doing various activities aiming at the revival of Ainu heritage during the last several decades, for example Asir Chep Nomi (Salmon Thanksgiving) Festival in Sapporo and Kantō based Ainu movement through a restaurant in Tokyo called Rera Chise (House of Wind). ${ }^{7}$ Even though the requests of formal recognition for being indigenous inhabitants and financial supports for cultural preservation have been raised for quite a long time, the changes merely became obvious after the enactment of the Ainu New Law in $1997 .{ }^{\circ}$ Especially regarding the land claims, I 
speculated that the iwor project was highly expected for the revival of Ainu traditions in Hokkaido. In Ainu language, iwor refers to a deep (remote) mountain, and also signifies the hunting ground of one village or joint hunting territory shared by several villages; therefore, it also means one's living area and maintains the boundary, symbolizing the sense of belonging. Iwor project combines financial supports and the return of land for traditional practices (similar to iriaiken that implies the right of using resources in a shared territory based on the local traditional practices) allowing them to bring the revival of local traditions. In 2001, I was told that there were altogether six proposals submitted from Sapporo, Shiraoi, Obihiro, Shizunai, Kushiro, and Piratori; and Lake Akan area was included as part of the Kushiro proposal. Yet, considering the cultural diversity in different regions, it was possible that three to four of them might get accepted rather than only one as mentioned in the beginning. It is not difficult to understand the controversy of just having one iwor project presenting the totality of Ainu culture. In particular, organizational disputes among regional groups have been acute during the last few years. These disputes reflect the increasingly recognized fact that Ainu culture is not monolithic or homogeneous, but has regional distinctions within, and different meanings to the various groups.

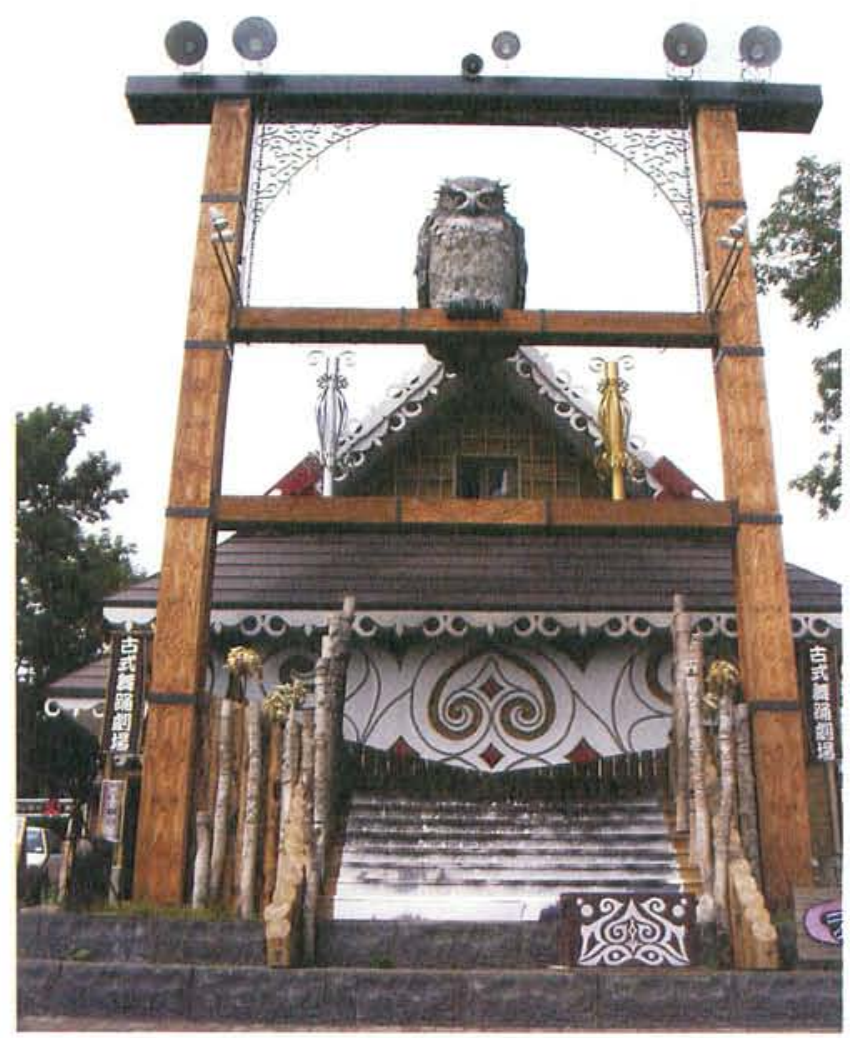

Figure 5.2: Entrance of the theatre in Akan Kotan.

During my visit in 2003, I found that Shiraoi was officially chosen as the core part of the iwor project while supporting facilities would be built in several places. Ainu people in Lake Akan were not as disappointed as I imagined. It is basically because a tourism destination such as Lake Akan can probably generate revenue from the increase of visitors, and the revival of Yukar Theatre was one of their tourism promotion strategies in 2004 (Figure 5.2). From 1 April until 20 May 2004, an Ainu theatre entitled "Yukar: Epic of the Hero" was performed two times a day, however many of my informants expressed that the results were not as good as they thought. The high expectation might be related to how people remembered the success of Ainu Yukar Theatre $^{9}$ performance in the 1970 s. However, with the long tourism-depended development in most Ainu settlements, traditional ritual has completely disappeared and new style cultural performances were never encouraged or built to bring out their own voices; again, due to the lack of support in innovating and promoting the art form of traditions, the performance of Yukar Theatre in 2004 indeed reflected the difficulties in Ainu heritage preservation.

Comparing the Bangarra Dance Theatre which took part in the indigenous segment of the opening and closing ceremonies of the Sydney 2000 Olympic Games and Ainu folk dance taken place in Lake Akan merely for tourists, it is obvious to say that Australian Aborigines' cultural representation has received different public recognition than Ainu people's folk performances mainly taken place in tourist destinations. Again, we need to understand the political meanings between Ainu Yukar Theatre and Bangarra Dance Theatre, as Kapferer (1988: 142-143) pointed out that the emphasis upon the harmonic unity with nature should be an important metaphor of egalitarianism within Australian nationalist ideology in differentiating themselves from Europe culture, and mentions that Australian Aboriginals "are often represented as the most ancient, older than anything in Europe, is important, quite apart from any empirical validity, within Australian nationalism" (1988: 142-143). But, even because of the differences between their social contexts, we might still find the apolitical aspects of Ainu cultural preservation in many ways. Being a similar indigenous traditional culture highly used for commercial activities in tourism industry, Desmond (1999) raised the fact that hula dance sometimes reflected issues of history connecting with the current political situations and even gave reference to sovereignty; furthermore, Desmond added that "some dances do include indirect references to the contemporary situation by stressing themes of justice and the perpetuation of Native Hawaiian values" (1999: 31). Therefore, in order to study how Ainu heritage has been promoted in contemporary Japanese society, I choose to look into the local context of Lake Akan for a better understanding.

\section{History of Lake Akan and its Social Development}

About the location of Lake Akan, anyone traveling from Sapporo (the major city in the southern part of Hokkaido) has to go to Kushiro or Kitami and then takes the local bus to reach the area. It is located in the eastern part of Hokkaido with Kushiro marshland on its south. In Ainu language, akan means stable as well as not moving, which enhances its stability given that there are active volcanoes and areas with hot springs around Lake Akan. ${ }^{10}$ Together with the lake (with an area of 13 square $\mathrm{km}$ and $38 \mathrm{~m}$ in depth), "male" mountain Akan (1317m in height) and "female" mountain Akan (1503m in height), a developed area along the coast of the lake with residential and business activities form the basic components of its physical landscape. Together with 
the natural scenery, hot springs, and the government recognized natural heritage (a kind of spherical algae called marimo found at the bottom of the lake) in 1921, Lake Akan has been a well-known tourist destination since the 1920s. In addition, with the establishment of Akan National Park in 1934, Lake Akan has been only recognized as an important tourist attraction in Hokkaido.

Looking into the history of Lake Akan, the earliest formal historical document was made by Matsuura Takeshirou in 1858, as mentioned by Irimoto (2001: 327); while the earliest economic development brought by Japanese was probably the forestry business of Maeda Masana, which began from 1906. The relations between the Maeda family and Akan Ainu were crucial because the establishment and success of the present Akan Kotan originated from the free use of land given to the Ainu people by Maeda Mitsuko, the third successor of the Maeda family. Regarding the development of Akan Kotan (kotan means settlement in Ainu language, also see Figure 5.3) as the indigenous settlements, I was told that there were only four households in 1951 since most Ainu were seasonal workers/artisans living somewhere else rather than in the Lake Akan area. In order to let most of them having a stable environment to earn their living and to concentrate on their works, in 1953, some Ainu people made their first appeal to Maeda Mitsuko asking if they could settle in the area. And, the agreement was only finalized in 1959, which allowed Ainu people to live and work in the present Ainu Kotan area without paying the Maeda family as well as the actual landlord. ${ }^{11}$ During my visits, I repeatedly asked many people about what kinds of usage had taken place on this piece of slight slope; however, no consistent answer was found. Some people told me that it was farm land before, while others told me that it was used to keep horses which were used for transportation in the old days; however, it was indeed true to say that it was a marginal residential area compared to center of Lake Akan tourism at that time.

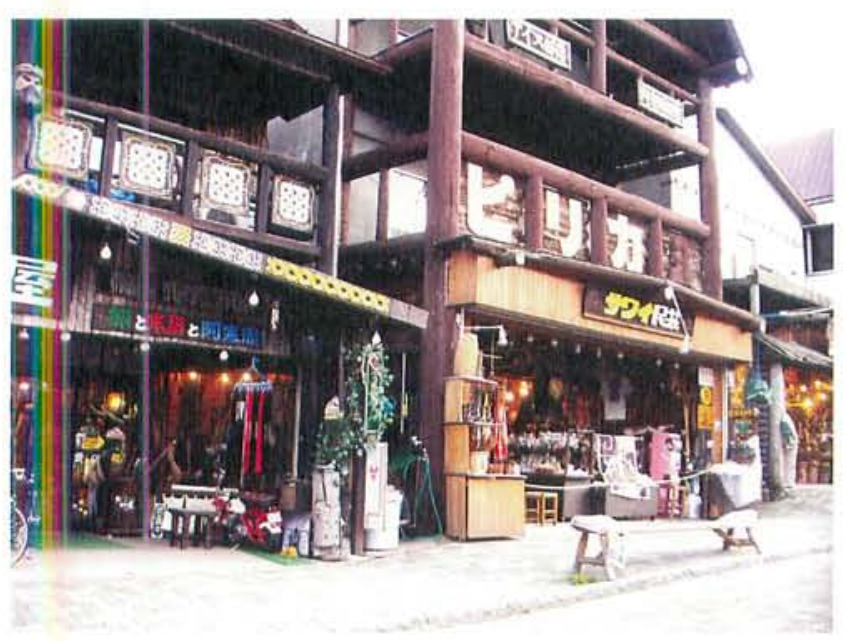

Figure 5.3: Close up of shops in Ainu Kotan.

One might ask about the present residents of the Lake Akan and whether they are local indigenous Ainu people. Actually, there are both Japanese and Ainu people living in that area and most of them as well as their fathers and grandfathers came from outside. Most Japanese came because of the tourism industry and worked in sectors such as hotel, souvenirs, food, and transportation. Regarding the present Ainu people living in Lake Akan, they belong neither to one single distinctive group with common origin or ancestor, nor regional ethnic group sharing common local traditions, specific lifeways, and socio-historic relations with the landscape. The so-called Akan Ainu is relatively a newly emerged self-identity among them given the majority came from many different areas outside the Lake Akan. In other words, Lake Akan signifies a renowned tourist attraction combining the beauty of nature and the indigenous culture of Ainu people. For example, I met Japanese who were attracted by Akan's mountains and have been living there for decades, and also some were attracted by outdoor activities such as hiking and fishing. Besides the many shops and hotels serving visitors, around thirty shops in the Ainu Kotan are selling souvenirs, offering Ainu food and together with the Ainu Theatre performing Ainu music and dance; most of the visitors are domestic tourists and the majority among international tourists came from Taiwan.

In the early period, most of the Ainu people in Lake Akan were seasonal workers as well as wood crafters coming from nearby areas such as Kushiro, Urakawa, Shirarika, Asahikawa, etc. In particular, Shitaku (2001: 38) mentioned that two or three souvenir shops with Ainu owners appeared as the number of domestic tourists increased in the late $1940 \mathrm{~s}^{12}$ Still most of the Ainu seasonal workers came to work in souvenir shops owned by Japanese and were particularly hired to craft wooden crawling bears (kibori kuma) in front of the shops as one of the tourist attractions in Lake Akan. Ironically, the decorative crawling bear woodcrafts might not be considered the "traditional skills" of Ainu people. It is because the idea of wooden crawling bear was in fact "imported" from Switzerland in 1922 by "a descendent of the Tokugawa family in Owari, settles in Yakumo and started up farms there" (Ohtsuka 2003: 139); while technical skills for producing it as a souvenir for tourist had been taught by Japanese in order to help the Ainu people earning livings after the collapse of their traditional lifeways of hunting and gathering. ${ }^{13}$

About the trends of souvenirs sold in Lake Akan in different periods, Shitaku (2001: 38) mentioned that souvenirs sold in the 1920 s were mainly postcards, wooden walking stick, and tobacco pipe; while in the 1930 s, wooden crawling bear was popular. Nowadays, I observed that the most popular woodcrafts sold in Lake Akan were tiny wooden accessories (with patterns related to Ainu, Lake Akan, or Hokkaido) for mobile phones.

Indeed the influences brought by ethnic tourism to Ainu settlements was becoming much more significant since the 1950s; number of Japanese tourists visiting Ainu villages began to grow much faster, and raised questions concerning the meanings of Ainu traditional culture and ethnicity from Japanese perspectives. For example, the image of Ainu with exotic facial features was commonly found in postcards, woodcrafts, and various souvenirs sold to Japanese tourists, group photographs taken with an Ainu chief in traditional costumes reflected the prevalent discourse on Japaneseness and emphasis on ethnic identity in the interest of self-conception, and last but not least, the emergence of ethnic souvenirs such as bear woodcrafts and Ainu couple dolls did in 
fact reveal the Ainu image in the Japanese mind. ${ }^{14}$

\section{Ainu Cultural Tradition in Lake Akan}

My first encounter with Ainu people in Lake Akan took place in the summer of 2001 when I was visiting several Ainu settlements in Hokkaido in order to gain a better understanding of the effects brought by the enactment of the Ainu New Law. After visiting Shiraoi and Nibutani in the southern part of Hokkaido, I went further to the eastern part through Kushiro and tried to interview some Ainu people in Lake Akan regarding their lifeways and changes taken place locally. Soon after I arrived, I went to a café with local color in the Ainu Kotan and started looking for the historical background and relevant information about Ainu people's lifeways in Lake Akan. It was not too long after our conversations began, my non-Japanese identity was revealed. They asked where I came from and how I learned to speak Japanese. I told them that I had studied in Japan but had moved back to work in Hong Kong for some years. Once I mentioned to them that I came from Hong Kong, the okäsan (meaning mother in Japanese) immediately told me that they had experienced some good times in Hong Kong in 1984. Immediately, they pulled out some pictures in their family albums and showed me the Iyomante dance performance they did on the temporary stage inside the Victoria Park in Hong Kong. In fact, that was probably one of the programs held during the Hong Kong Asian Arts Festival organized by the Government in order to enhance the knowledge of different kinds of Asian art forms such as music, drama, and dance among Hong Kong citizens. That encounter turned out to be the beginning of the long-term friendship between me and this family A.

Talking about the geographic distribution of family A, they were indeed living with a pattern which inspired me in thinking about the ethnoscapic flow of Ainu people in contemporary Japanese society. In family A, the father was originally from Kushiro while the mother was from Urakawa. They have three children and all of them grew up in Lake Akan. During the last few years, one of them has been living in Honshu not doing any Ainu-related work. For the two who were married, their spouses were Japanese but were substantially influenced by the Ainu lifeways and were actively involved in promoting Ainu traditions in different ways such as selling handcrafts, singing and dancing performance. One couple has moved to Honshu, while the other remained in Hokkaido living with the parents in Hokkaido. Therefore, it is obvious that members of family A not only moved from their home areas to places with more (tourism related) job opportunities within Hokkaido, but also moved to the Kanto area for a wider choice of careers.

A similar pattern was found in family B from whom I received a great deal of support during my field research on the social development of Lake Akan. In family B, both the Ainu father and the Japanese mother were from Kushiro, and had been living in Lake Akan for a few decades. Their two children were living with them, and only one was working on traditional Ainu dance performance while the other was not. More importantly, the father of the Japanese wife used to be the curator of the Kushiro City Hall in the 1970s and was a recognized figure in promoting Ainu culture not only to the Japanese society but also to worldwide audiences.
His efforts were remembered in particular for making Ainu Yukar Theatre well-known and successfully presented/performed both through the arrangements of United Nations Educational, Scientific and Cultural Organization (UNESCO) and the Guimet Museum in Paris in 1976; a number of senior Ainu residents in Lake Akan recalled their good old times and were proud of telling me about that.

Regarding the proceeds from Lake Akan's tourism development since the 1980 s, the father of family B told me that they became busy with their own living and did not continue the performance of Ainu Yukar Theatre. He added that they occasionally performed it for the sake of cultural exchange (only upon invitation) and did not consider it for commercial purposes until recently. Therefore, on one hand, we can see how tourism development which makes Lake Akan a unique place in the sense that Ainu people could preserve and promote their heritage as well as folk traditions openly, on the other hand, the kind of tourism oriented development did not give space for the consideration of heritage preservation without the commercial implications. Both families A and B are not exceptional cases in Lake Akan regarding their involvement with the promotion of Ainu culture in Lake Akan, and it is significant to look into issues such as how Lake Akan has played the role of a transit among Ainu people in Hokkaido.

As I was told that the major incomes were mostly determined by the tourists, and the local community was supported by revenue generated through tourism industry including hotels, restaurants, souvenir shops, travels, etc. during the last few decades. From the local perspective, they also admitted that tourism industry helped to preserve Ainu culture in some ways. Since Ainu culture has been the major attraction of Lake Akan, and there are at least four institutes involved in either preserving or promoting Ainu culture despite the fact that most Ainu descendants who can neither speak the language nor carry out any Ainu traditional practices and rituals. They are the Akan Branch of the Ainu Association of Hokkaido, Akan Ainu Industrial Association, Lake Akan Ainu Association, and Lake Akan Ainu Culture Preservation Society.

In particular, the Lake Akan Ainu Culture Preservation Society was found in 1968 with the objectives for preserving traditional dance, language, and Yukar Theatre in Lake Akan, and also aiming at participating cultural activities in Japan in order to promote Ainu culture countrywide. Again, cultural exchanges in the forms of traditional dances and folk music performances between Akan Ainu and other countries are very popular. During the 1970s, Ainu Yukar Theatre in fact received quite a lot of attentions and was invited to perform in Sapporo (1972), Kushiro (1973), Akan-chō (1976), Tokyo (1976), and particularly the two performances in Paris (1976) being part of the Japan Festival supported by the Japanese Government for the sake of disseminating Japanese culture to the world. Starting from the 1980s, members of the Akan Yukar Theater, a group of performing artists in Akan area, have been going to Hong Kong, Taiwan, Australia, North America (Alaska, Canada), and Europe (France, Italy), participating in several major international arts events.

Lake Akan has been a famous tourist destination for wooden souvenirs crafted by Ainu artisans, but nowadays it 
is even more well-known for several artists who are based in Lake Akan. As I have mentioned before, most of the woodcrafters were seasonal workers who had merely stayed in Lake Akan during the tourism season but settled down after Maeda family gave them the free land usage in the present Ainu Kotan. Besides Ainu people who came and settled in Lake Akan, there were also some Japanese who came for their art works. It was obvious to find that motifs of their woodcrafts were often mixed with Ainu traditions, indigenousness, natural sceneries, animals etc., and those indirect relations with the Ainu indigenous culture have in fact showed the complexity of Ainu heritage.

Regarding the controversy of Ainu tradition and relevant divergence between Ainu and some outsiders (mainly Japanese), a local festival in Lake Akan serves a good example for our understanding. The debate over the authenticity of the tradition of marimo-sai (sai means festival in Japanese) is one instance which highlights the discrepancy between the definitions of traditional culture held by the mass public, and those by Ainu people who recognize the inheritance of spiritual value rather than the maintenance of an ancient cultural practice from unidentified origin in the past. ${ }^{15}$

Before going further, let me briefly explain the origin of the marimo festival in Lake Akan. In the early 1920s, marimo was recognized as important natural heritage by the Japanese government; however, this spherical algae was continuously taken from Lake Akan and even sold as souvenirs outside the Akan area. In the 1940s, marimo was found endangered because of being stolen and the environmental change happened in Lake Akan. Therefore, in order to preserve marimo from vanishing, local Ainu people began the festival symbolizing a ritual of return as well as the harmony of human and nature. According to traditional Ainu cosmology, there were two worlds-the human world and the supernatural world. They existed mutually, and living beings could transport from one to another easily. In particular, from the Ainu's point of view, an animal was a spiritual visitor, symbolizing the gain of natural resources, and serving as a messenger who bridged human society and the supernatural world; therefore, their visit in the form of animals to the Ainu's world actually denoted the gift-giving between man and the supernatural in the Ainu cosmos. Similar explanation was used in the marimo sai as a form of return; with the emphasis upon the marimo's return to nature, marimo festival was well accepted as the representation of Ainu cosmology and the festival has been continuously held in October every year.

Nonetheless, regarding this fifty years tradition of the festival, there has been a discrepancy between local Ainu people who believe that the festival is characterized by the Ainu's traditional idea emphasizing the importance of returning on receiving (symbolizing the harmony between human beings and nature) and outsiders who argue that marimo festival is merely an "invented" traditional in Akan for some purposes. ${ }^{16}$ As from the debate on the authenticity of Ainu tradition, we realize that Ainu culture represents the meaningful selective mix of practices and knowledge and is particularly recognized by people who see indigenous traditional as the counterpart of the mainstream culture. Actually, since 1970 s, grassroots indigenous movements organized by Ainu people have become more obvious, especially in seeking their indigenous rights in a national rather than another perspective. Moreover, the process has not always been peaceful, for example, there were protests against the Japanese Society of Ethnology in the late 1960s, a sculpture was bombed to destruction in Asahikawa in 1972, and a lawsuit for portrait rights was undertaken in 1985 which showed the underlying hostility. ${ }^{17}$ Doubtlessly, what has changed most since the 1970s is the awareness among Ainu people that they need to preserve their cultural traditions for their descendants; however, there remain only a few Ainu who are able to speak Ainu as their mother tongue and almost none of them are practicing the traditional lifeways. So, we will ask if it is possible to recover and reconstruct Ainu heritage nowadays.

\section{Conclusion}

In different parts of the world, indigenous living grounds were taken away by the authority from the people without much justification; however, when indigenous people claim for their rights over land use, they need to provide all kinds of justifications in order to support having their former living ground returned. Even though some indigenous groups succeed in their land claims, the procedure is usually long and contains different stages. The social development of Ainu Kotan in Lake Akan not only demonstrated the typical example of this slow return of sovereignty but also provided an excellent observation for the understanding of the future of Ainu heritage preservation in Japan. For the slow return of land use, we can see how Ainu's indigenous living environment was taken away by the Meiji government and was later fallen into the hand of the Maeda family; out of sympathy, a small piece of land was given to some Ainu seasonal workers, which turned out to be the base of preserving Ainu heritage. Considering how they set foot in Lake Akan and presented Ainu traditional music, Ainu folk dance, and Yukar Theatre to the visitors, I suggest that there are at least two unique aspects shown in the social development of Ainu Kotan in Lake Akan: firstly, most of the Ainu people were outsiders, they came and settled in Akan because of the free use of land given by the Maeda family; secondly, Lake Akan is a tourism oriented place and Akan Ainu are used to performing traditional dance and music to visitors, even though the invention of marimo festival. Finally, the future of Ainu heritage depends on how the indigenous rights of Ainu will be recognized on both individual and national levels. With the Nogaku Theatre and Ningyo Johruri Bunraku Puppet Theatre being proclaimed by UNESCO as the Masterpieces of the Oral and Intangible Heritage of Humanity in 2001 and 2003 respectively, one might ask if Ainu Yukar will be proclaimed as well as recognized at the international level for being one of the three ancient epics in the world. However, I guess it will not be possible until more Japanese people consider the necessity of understanding and preserving Ainu heritage from a mutual perspective given that Japanese government can seriously consider the urgency and importance of preserving Ainu's tangible and intangible heritage for the coming generations.

\section{Acknowledgements}

The initial research for this chapter was made possible by a grant from Sumitomo Foundation (Japan) for the research 
project entitled "Rethinking Ainu Identity: An Ethnographic Study of Ainu Folk Art in Lake Akan, Hokkaido."

\section{Notes}

1. For more details, see Siddle, Race, Resistance and the Ainu of Japan, 1996; and Howell, 'Making 'Useful Citizens' of Ainu Subjects in Early Twentieth-Century Japan,' 2004.

2. See Cheung, 'Japanese Anthropology and Depictions of the Ainu,' 2004.

3. For more details, see Uemura, Modernity of Indigenous People [in Japanese], 2001; and Miyatake, 'Ainu and Saint Louis Olympic Games of 1904 [in Japanese], 2002.

4. For more details, see Hilger, 'Japan's "Sky People," the Vanishing Ainu,' 1967; Together with the Ainu, a Vanishing People, 1971.

5. Books such as Peng and Geiser, The Ainu: The Past in the Present, 1977; Siddle, Race, Resistance and the Ainu of Japan, 1996; and Sjoberg, The Return of the Ainu: Cultural Mobilization and the Practice of Ethnicity in Japan, 1993 provided important information since the 1970s, and Fitzhugh and Dubreuil eds., Ainu: Spirit of a Northern People, 1999 was probably the last but best comprehensive work in the twentieth-century.

6. See Aoki, The Transformation of 'Japanese Cultural Studies': Culture and Identity in Postwar Japan [in Japanese], 1990.

7. For the revival of Ainu heritage in the forms of music, festival and food, see reports made by Peter Hadfield, "Ancient Ainu emerge from the shadows: Country's original inhabitants take new pride in their long-marginalized culture and language," South China Morning Post, 23/05/2001; Tomek Bogdanowicz, "Where are the Ainu now? In search of answers about Japan's indigenous people," The Japan Times, 02/03/2003; and Tomek Bogdanowicz, "Ainu Revival: A feast of culture on Hokkaido menu," The Japan Times, 27/06/2004.

8. Ainu New Law (Ainu Shinpō) was drafted and proposed in 1984, and finally passed on 8 May 1997. It seems that the Japanese government has finally given formal recognition to the Ainu as the indigenous minority within Japanese territory, at least in Hokkaido, even though the general reaction to the endorsement was its late coming. Yet with the initial move, Ainu people expected more cultural (preservation of language, tradition etc.) and legal (land use, discrimination issues etc.) recognition regarding Ainu people's social status in Japan. For the details and developments of the Ainu New Law, see Stevens, 'The Ainu and Human Rights: Domestic and International Legal Protections,' 2001; Siddle, 'An epoch-making event? The 1997 Ainu Cultural Promotion Act and its impact,' 2002; and Cheung, 'Ainu Culture in Transition', 2003.

9. Ainu Yukar is considered one of the three ancient epics in the world; Ainu Yukar Theatre is the stage drama selected from episodes of the epic.

10. See Yamamoto, Akan National Park and Legend of Ainu [in Japanese], 2003 [1940].

11. See Akan-chō History Committee, One Hundred Years at Akan-chō [in Japanese], 1986.
12. See Shitaku, Ainu oma (aynu ga yuku) [in Japanese], 2001.

13. For the details of early development of woodcrafts among Ainu, see Low, 'Contemporary Ainu Wood and Stone Carving,' 1976; Shitaku, Ainu oma (aynu ga yuku) [in Japanese], 2001; and Ohtsuka, 'Ainu Handicraft-Tracing Its History', 2003.

14. For the relations between Ainu and Japanese people in the context of tourism development, see Cheung, 'Change of Ainu Images in Japan: A Reflexive Study of Pre-war and Post-war Photo-images of Ainu', 1996; 'Men, Women and 'Japanese' as Outsiders: A Case Study of Postcards with Ainu Images', 2000.

15. See Irimoto, "Marimo Matsuri no Sōzō: Ainu no Kizokusei to Minzokuteki Kyōsei" (Creation of the Marimo Festival: Ainu Identity and Ethnic Symbiosis) 2001.

16. See Lake Akan Ainu Association, Retrospect of Marimo Festival in 50th Year Anniversary [in Japanese], 2000.

17. Shimizu, 'Cooperation, not domination: a rejoinder to Niessen on the Ainu exhibition at Minpaku', 1996.

\section{References Cited}

Akan-chō History Committee. 1986. One Hundred Years at Akan-chō [Akan-chō Hyakunenshi]. Akan: Akan-chō Yakuba.

Aoki, Tamotsu. 1990. The Transformation of 'Japanese Cultural Studies': Culture and Identity in Postwar Japan [in Japanese] Tokyo: Chūō Kōronsha.

Cheung, Sidney C.H. 1996. "Change of Ainu Images in Japan: A Reflexive Study of Pre-war and Post-war Photoimages of Ainu." Visual Anthropology 9: 1-24.

_. 2000. "Men, Women and "Japanese" as Outsiders: A Case Study of Postcards with Ainu Images." Visual Anthropology 13: 227-255.

2003. "Ainu Culture in Transition." Futures: The Journal of Policy, Planning and Futures Studies 35: 951-959.

_. 2004. "Japanese Anthropology and Depictions of the Ainu." Pp. 136-151 in The Making of Anthropology in East and Southeast Asia, eds. Shinji Yamashita, Joseph Bosco, and Jerry S. Eades. New York: Berghahn Books.

Desmond, Jane. 1999. Staging Tourism: Bodies on Display from Waikiki to Sea World. Chicago: University of Chicago Press.

Fitzhugh, W. W., and C. O. Dubreuil eds. 1999. Ainu: Spirit of a Northern People. Seattle: University of Washington Press.

Hilger, M. Inez. 1967. “Japan's 'Sky People', the Vanishing Ainu." National Geographic 131: 268-296.

_ 1971. Together with the Ainu, a Vanishing People. Norman: University of Oklahoma Press.

Howell, David L. 2004. "Making 'Useful Citizens' of Ainu Subjects in Early Twentieth-Century Japan." The Journal of Asian Studies 63: 5-29.

Irimoto, Takashi. 2001. "Marimo Matsuri no Sōzō: Ainu no Kizokusei to Minzokuteki Kyōsei" (Creation of the Marimo Festival: Ainu Identity and Ethnic Symbiosis). Minzokugaku Kenkyü (The Japanese Journal of Ethnology). 66(3): 320-342.

Kapferer, Bruce. 1988. Legends of People, Myths of State: 
Violence, Intolerance, and Political Culture in Sri Lanka and Australia. Washington, D.C.: Smithsonian Institution Press.

Lake Akan Ainu Association. 2000. Retrospect of Marimo Festival in 50-Year Anniversary [Marimo Matsuri 50 nen no Ayumi]. Akan: Lake Akan Ainu Association.

Low, Setha M. 1976. "Contemporary Ainu Wood and Stone Carving” Pp. 211-225 in Ethnic and Tourist Arts: Cultural Expressions from the Fourth World, ed. Nelson Graburn. Berkeley: University of California Press.

Miyatake, Kimio. 2002. "Anthropology and "Anthropology Days": Ainu and 1904 St. Louis Olympic Games" [Jinruigaku to Orinpikku: Ainu to 1904 nen Sentoruisu Orinpikku Taikai], The Annual Report on Cultural Science (Hokkaido Daigaku Bungaku Kenkyū-ka Kiyō) 108: $1-22$.

Ohtsuka, Kazuyoshi. 2003. "Ainu Handicraft: Tracing Its History." Pp. 128-144 in Message from the Ainu: Craft and Spirit, Sapporo: The Foundation for Research and Promotion of Ainu Culture.

Peng, Fred C. C., and Peter Geiser. 1977. The Ainu: The Past in the Present. Hiroshima: Bunka Hyoron Publishing Company.

Shimizu, Akitoshi. 1996. "Cooperation, not Domination: A Rejoinder to Niessen on the Ainu Exhibition at Minpaku." Museum Anthropology 20: 120-131.

Shitaku, Toyojiro. 2001. Ainu oman (aynu ga yuku), Part 1. Kushiro: Fuji Print.

Siddle, Richard. 1996. Race, Resistance and the Ainu of Japan. London and New York: Routledge.

_ 2002. "An Epoch-Making Event? The 1997 Ainu Cultural Promotion Act and its Impact." Japan Forum 14: 405-423.

Sjoberg, Katarina. 1993. The Return of the Ainu: Cultural Mobilization and the Practice of Ethnicity in Japan. Amsterdam: Harwood Academic Publishers.

Stevens, Georgina. 2001. "The Ainu and Human Rights: Domestic and International Legal Protections." Japanese Studies 21: 181-198.

Uemura, Hideaki. 2001. Senjū Minzoku no "Kindai-shi": Shokuminchi-shugi wo Koeru Tame ni [The Modern History of Indigenous Peoples: Towards Transcending Colonialism]. Tokyo: Heibonsha.

Yamamoto, Tasuke. 2003 [1940]. Akan Kokuritsu Kōen to Ainu no Densetsu [Akan National Park and Legend of Ainu] Tokyo: Sōfūkan.

\section{アイヌ遺産の再考一北海道アイヌ集落のケー ススタディ}

\section{張 展鴻}

明治時代から始まった北海道開拓期に、西洋技術が日本 に採り入れられる一方で、同化政策によりアイ又原住民の 人々の生活様式は負の影彎を受けた。本論文では、まずア イ又集落の歴史的発展を紹介し、次にアイヌの伝統につい ての論争の意義を説明する。更に文化政治的な钼点から戦 後日本によけるアイヌ文化の形成について考察する。阿寒 湖のアイ又集落に焦点を当て、日本社会のグローバリゼー
ションに伴いアイヌの遺産はどのように保護・宣伝され、 アイヌの人々はどのような社会的変化を経験してきたかを 見るため、過去数十年で変化し続けた原住民の生活環境と それに関連する活動を詳述する。

日本の社会政治的変化の中でのアイヌ文化の意味を 理解するためには、戦後の日本文化の意義の変化を検討す ることが重要である。第二次世界大戦の敗戦により、日本 国民に劇的な変化がもたらされ、日本人としてのセルフ・ アイデンティティの追求が社会復興に必要だと考えられて いた。日本の経済的、政治的、軍事的変化には西洋文化と 技術の輸入が非常に大きな影響を及ぼした。また、天皇陛 下の人間宣言によって日本人はセルフ・アイデンティティ の基盤を新たに模索していくことになった。アメリカの大 衆文化、商業化、都市化が戦後日本に流入し、いわゆる日 本の文化的伝統を摇るがすものとなった。これらの要素が 知らぬ間に日本人の社会的価值钼に変化をもたらし、特に 1960年代以降、経済大国としての発展が始まった。特に、 このアイデンティティ・クライシスは日本人学者や大衆作 家による膨大な日本人論に見ることが出来る。日本人らし さについての議論はアイデンティティの危機を反映してい るもので、反対にそれは先住民、移民、外国人を含む非日 本人という他者に対する日本社会の態度の変化を象徴して いるものでもあった。それゆえ、戦後の日本人らしさにつ いての議論の出現は日本社会の変化を示しており、それ は、国民的、または文化的アイデンティティの形成のプロ セスの理解へと慗がるのである。

戦後の贫困と政治的劣勢から回復した後、国際社会での 経済的成功と承認によって、ナショナル・アイデンティテ イと日本人らしさの探求が始まった。そのような急速な社 会変化の中でアイヌの人々の状況はどうであったのだろう か。アイヌの人々は過去数十年の間、アイヌ遺産の復興の ために様々な活動を行い、先住民としての正式な承認と文 化保護のための経済的な支援を長い間求めていたのだが、 それが明らかになってきたのは1997年のアイヌ新法制定後 であった。特に、土地所有権に関するイウォロプロジェク トは、北海道でアイヌの伝統復興として高く期待されたも のだった。イウォロブロジェクトは伝統復興のために、伝 統的慣例を行うための経済的支援と土地の返還を同時に実 行したものである。2001年に、札幌、白老、带広、静内、 釧路、ピラトリの六地域の返還提案がなされ、阿寒湖は 釧路提案の一部に含まれていた。各地の文化の多様性を考 慮し、1地域だけでなく3〜4地域受け入れられる可能性は あった。なぜなら、1地域だけがイウォプロジェクトによ って全アイヌ文化の代表になるならば、それが論争になる ことは容易に理解できたからである。特に、過去数年間の 地域グループ間での大規模の議論は深刻なものであった。 これらの議論はアイヌ文化が単一的で同質的なものではな く、それぞれのグループによって地域的特徴が異なるとい うことが、ますます認識されてきたことの現れなのであ る。

2003年の訪問時には、イウォプロジェクトの中心地とし て白老地区が公式に選定され、その他数筒所に支援施設が 設立されることになっていた。その結果に対し、阿寒湖の アイヌの人々は私が予測していたほど失望してはいなかっ た。それは、おそらく阿寒湖のような钼光地では基本的に 観光客の増加で収入を得ることがでさるからであり、2004 年の観光宣伝戦略の一つにユーカラ劇の復興があったから であろう。2004年4月1日から5月20日まで、毎日2回「ユー カラ：勇壮な英雄」という題名のアイヌ劇が上演された が、多くの情報提供者によれば反響は彼らが思っていたほ どはよくなかった。1970年代に上演されたアイヌユーカラ 
劇の成功を受けて、今回も期待が高まっていたのである。 しかし、ほとんどのアイヌ集落が長期的に観光依存によっ て発展を遂げてきたために、伝統的儀式は完全になくな り、彼ら自身の声を反映した新しいスタイルの演技の追求 や構築もなされてこなかったのである。それは、支援者の 久如と、演劇という無形伝統芸能の振興の欠如のゆえであ る。2004年のユーカラ劇の上演は、まさにアイヌ遺产保護 の難しさを反映したものとなった。

\section{プロフィール}

張展鴻教授 (博士、大阪大学) は、香港中文大学で人類学 科長と文化遺産研究センターの副センター長を兼任してい る。張氏はこれまでに、日本、香港、中国本土、東南アジ アでフィールドワークを実施し、映像人類学、観光人類 学、文化遺産、食文化、そしてアイデンティティについて の研究を発表してきた。編著にOn the South China Track: Perspectives on Anthropological Research and Teaching (1998年)、 共編著にTourism, Anthropology and China (2001年) やThe Globalization of Chinese Food (2002年)、そしてFood and Foodways in Asia: Resource, Tradition and Cooking (2007年) がある。学術 書の他に、『香港漁民の民族誌』（香港、2009年）や『路 上のシェフたち』（香港、2009年）という中国語の本が香 港で出版され、一般読者にも人類学的な視点を紹介してい る。 